5-1-2021

\title{
Cold Tolerance of Mountain Stoneflies (Plecoptera: Nemouridae) from the High Rocky Mountains
}

Scott Hotaling

Alisha A. Shah

Michael E. Dillon

J. Joseph Giersch

Lusha M. Tronstad

See next page for additional authors

Follow this and additional works at: https://bearworks.missouristate.edu/articles-cnas

\section{Recommended Citation}

Hotaling, Scott, Alisha A. Shah, Michael E. Dillon, J. Joseph Giersch, Lusha M. Tronstad, Debra S. Finn, H. Arthur Woods, and Joanna L. Kelley. "Cold tolerance of mountain stoneflies (Plecoptera: Nemouridae) from the high Rocky Mountains." Western North American Naturalist 81, no. 1 (2021): 54-62.

This article or document was made available through BearWorks, the institutional repository of Missouri State University. The work contained in it may be protected by copyright and require permission of the copyright holder for reuse or redistribution.

For more information, please contact BearWorks@library.missouristate.edu. 


\section{Authors}

Scott Hotaling, Alisha A. Shah, Michael E. Dillon, J. Joseph Giersch, Lusha M. Tronstad, Debra S. Finn, H. Arthur Woods, and Joanna L. Kelley 


\title{
Cold tolerance of mountain stoneflies (Plecoptera: Nemouridae) from the high Rocky Mountains
}

\author{
Scott Hotaling ${ }^{1}, * \dagger$, Alisha A. Shah ${ }^{2, \dagger}$, Michael E. Dillon ${ }^{3}$, J. Joseph Giersch ${ }^{4}$, \\ Lusha M. TronstaD ${ }^{5}$, Debra S. Finn 6 , H. Arthur Woods ${ }^{2}$, and Joanna L. Kelley ${ }^{1}$ \\ ${ }^{1}$ School of Biological Sciences, Washington State University, Pullman, WA \\ ${ }^{2}$ Division of Biological Sciences, University of Montana, Missoula, MT \\ ${ }^{3}$ Department of Zoology and Physiology and Program in Ecology, University of Wyoming, Laramie, WY \\ ${ }^{4}$ Northern Rocky Mountain Science Center, U.S. Geological Survey, West Glacier, MT \\ ${ }^{5}$ Wyoming Natural Diversity Database, University of Wyoming, Laramie, WY \\ ${ }^{6}$ Department of Biology, Missouri State University, Springfield, MO
}

\begin{abstract}
How aquatic insects cope with cold temperatures is poorly understood. This is particularly true for high-elevation species, which often experience a seasonal risk of freezing. In the Rocky Mountains, nemourid stoneflies (Plecoptera: Nemouridae) are a major component of mountain stream biodiversity and are typically found in streams fed by glaciers and snowfields, which are rapidly receding due to climate change. Predicting the effects of climate change on mountain stoneflies is difficult because their thermal physiology is largely unknown. We investigated cold tolerance of several alpine stoneflies (Lednia tumana, Lednia tetonica, and Zapada spp.) from the Rocky Mountains, USA. We measured the supercooling point (SCP) and tolerance to ice enclosure of late-instar nymphs collected from a range of thermal regimes. SCPs varied among species and populations, with the lowest SCP measured for nymphs from an alpine pond, which was much more likely to freeze solid in winter than flowing streams. We also show that L. tumana cannot survive being enclosed in ice, even for short periods of time $(<3 \mathrm{~h})$ at relatively mild temperatures $\left(-0.5^{\circ} \mathrm{C}\right)$. Our results indicate that high-elevation stoneflies at greater risk of freezing may have correspondingly lower SCPs, and despite their common association with glacial meltwater, these stoneflies appear to be living near their lower thermal limits.
\end{abstract}

RESUMEN.-No se comprende bien sobre cómo los insectos acuáticos pueden sobrellevar las temperaturas muy bajas. Esto es particularmente cierto para especies que habitan en elevaciones muy altas y que con frecuencia experimentan un riesgo de congelamiento estacional. En las montañas rocosas, las moscas de la roca (Plecóptera: Nemouridae), son un componente importante de la biodiversidad de los arroyos de montaña y se encuentran típicamente en arroyos alimentados por glaciares y campos de nieve que, debido al cambio climático, están retrocediendo rápidamente. El predecir los efectos del cambio climático en esta especie de plecópteros es difícil puesto que su fisiología térmica es en gran parte desconocida. Hemos investigado la tolerancia al frío de varias moscas de roca alpinas (Lednia tumana, Lednia tetonica, and Zapada spp.) de las montañas rocosas de los Estados Unidos. Hemos medido un punto de sobreenfriamiento y la tolerancia al hielo en confinamiento de ninfas en estadio tardío colectadas de un rango de regímenes térmicos. Los puntos de sobreenfrimiento variaron entre las especies y las poblaciones, las más bajas en los puntos de sobreenfrimiento fueron las ninfas de un estanque alpino, que era más susceptible a congelarse en el invierno que los arroyos de agua corriente. También encontramos que L. tumana no puede sobrevivir estando encerrada en hielo, aún en pequeños periodos de tiempo $(<3 \mathrm{~h})$ en temperaturas relativamente moderadas $\left(-0.5{ }^{\circ} \mathrm{C}\right)$. Nuestros resultados indican que las moscas de roca en elevaciones prominentes con mayor riesgo de congelamiento pueden tener correspondientemente un bajo punto de sobreenfrimiento, y a pesar de su asociación común con el agua de deshielo glacial, estas moscas parecen habitar cerca de sus límites bajos térmicos.

Freshwater habitats in cold regions typically experience winter ice cover and freezing temperatures, which can be injurious or lethal to aquatic insects (Danks 2008). Resident species may avoid extreme cold by moving to warmer or more thermally stable microclimates or by modifying local conditions (e.g., through casemaking; Danks 1971). Others withstand cold conditions in situ through supercooling (i.e., maintaining internal water in liquid form below

*Corresponding author: scott.hotaling@wsu.edu †Contributed equally 
its freezing point) or freeze tolerance (Zachariassen 1985, Danks 2008, Sinclair et al. 2015). Organisms living in wet environments are likely to encounter external ice when their body temperatures are already at or near freezing. Thus, inoculative freezing, in which contact with external ice induces the formation of internal ice, is likely the main driver of organismal freezing in these habitats (Frisbie and Lee 1997).

At high elevations, aquatic habitats are typically distributed across a mosaic of streams and ponds that are fed by an array of hydrological sources (e.g., glaciers, perennial snowfields, subterranean ice; Hotaling et al. 2017, Brighenti et al. 2021). These habitats remain snow covered for much of the year (Lencioni 2004). Mountain streams do not freeze solid because of their steep gradients and yearround flow, with minimum temperatures often close to $0{ }^{\circ} \mathrm{C}$ in the main channel (Giersch et al. 2017, Shah et al. 2017, Tronstad et al. 2020). Resident taxa are therefore predicted to experience minimum temperatures of $\sim 0{ }^{\circ} \mathrm{C}$. This prediction rests on the assumption that overwintering nymphs remain in the unfrozen primary stream channel throughout the winter season. However, because of the inherent variation in aquatic habitats, nymphs inhabiting different regions of a stream (e.g., littoral zone, bed sediments) may experience subfreezing temperatures, even when the rest of the stream remains unfrozen (Lencioni 2004). Alpine ponds, in contrast, have little or no flow and are often shallow, making them susceptible to freezing solid (Wissinger et al. 2016). As meltinduced flows are reduced in the future under climate change (Huss and Hock 2018), headwater streams will become shallower with less flow velocity, raising the risk of freezing in all seasons for resident organisms.

Stoneflies (order Plecoptera) inhabit every continent except Antarctica and, when present, often represent a substantial portion of aquatic biodiversity (DeWalt et al. 2015). After hatching, stoneflies follow a 2 -stage life cycle, with development through multiple instars as aquatic larval nymphs followed by emergence as winged terrestrial adults. Whether development occurs in a single year or spans multiple seasons, eggs and larvae of high-elevation stoneflies are exposed to near freezing temperatures. Cold tolerance of stoneflies and of aquatic insects in general is not well known, particularly for nonadult life stages (i.e., eggs or nymphs; Danks 2008) and for species living at high latitudes and elevations, where taxa are most likely to experience freezing. Aquatic insects generally employ an array of physiological and biochemical strategies to mitigate cold stress (reviewed by Lencioni et al. 2004). These include production of cryoprotectants to lower the temperature of internal ice formation (Duman 2015); cryoprotective dehydration, in which body water is lost to lower the amount available for freezing (e.g., Gehrken and Sømme 1987); and resistance to anoxic conditions induced by ice enclosure (e.g., Brittain and Nagell 1981). Eggs of the stonefly Arcynopteryx compacta (Perlodidae) from the mountains of southern Norway avoid freezing by supercooling to $-31{ }^{\circ} \mathrm{C}$, a trait mediated by the loss of approximately two-thirds of the eggs' water content (Gehrken and Sømme 1987, Gehrken 1989). Nymphs of another highlatitude stonefly, Nemoura arctica (Nemouridae), survive freezing to well below $0{ }^{\circ} \mathrm{C}$ by preventing intracellular ice formation through the production of a xylomannan-based glycolipid. This glycolipid inhibits inoculative freezing through the inactivation of ice nucleating agents (Walters et al. 2009, 2011). However, it is unlikely that glycolipid production represents a singular "magic bullet" that confers freeze tolerance in stoneflies, or aquatic insects broadly, given the diversity of known freezeprotecting molecules (Toxopeus and Sinclair 2018). Like $N$. arctica, high-alpine nemourids in North America appear to overwinter as early-instar nymphs (Supplementary Material 1) and may be exposed to a similar risk of freezing. How they cope with such risks, however, has not been investigated.

In this study, we investigated cold tolerance across populations of late-instar nymphs from at least 3 species-Lednia tumana (Ricker 1952), Lednia tetonica Baumann \& Call 2010, and Zapada spp.; Nemouridae-in the northern Rocky Mountains, USA. For all populations, we measured the dry supercooling point (SCP), which is the temperature at which an organism releases latent heat indicative of ice formation (Sinclair et al. 2015) in the absence of ice. Enclosure in ice may also be a major risk for mountain stoneflies, especially in slower-flowing shallow streams. Ice enclosure can cause mortality through inoculative freezing, hypoxia, mechanical damage, or a combination of these factors (Conradi-Larsen and 


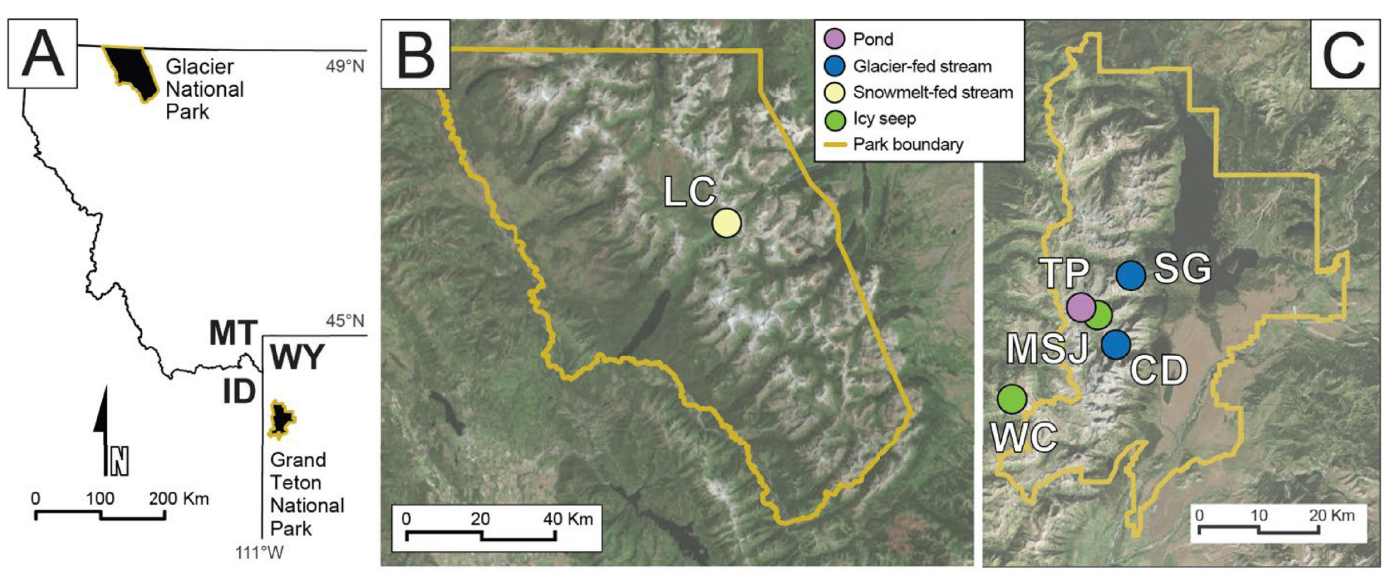

Fig. 1. Populations and habitat types included in this study. A, Locations of the focal ranges in the Rocky Mountains. B, Glacier National Park, Montana, USA. C, Grand Teton National Park and surrounding mountains, Wyoming, USA. Population initialisms: $\mathrm{LC}=$ Lunch Creek, $\mathrm{WC}=$ Wind Cave, $\mathrm{SG}=$ Skillet Glacier, $\mathrm{CD}=$ Cloudveil Dome, $\mathrm{MSJ}=$ Mount Saint John, and TP = Tetonica Pond.

Sømme 1973). One nemourid, N. arctica, can survive ice enclosure (Walters et al. 2009), but how widespread this ability is among stoneflies is unknown. Thus, for one population from Lunch Creek, we also tested whether nymphs could survive ice enclosure. Given the perennial and fast-flowing conditions of alpine streams, we expected winter conditions to be largely constant, with temperatures near $0{ }^{\circ} \mathrm{C}$, and likelihood of freezing to be generally low. Therefore, we did not expect stonefly SCPs to vary among stream-inhabiting populations. Conversely, because high-elevation pond-dwelling stoneflies likely experience a greater risk of freezing, we expected resident nymphs to exhibit lower SCPs. Furthermore, given that $N$. arctica nymphs can survive being enclosed in ice and that streams containing Lednia are commonly near $0{ }^{\circ} \mathrm{C}$ even in summer (Supplementary Material 2), we expected L. tumana nymphs to survive ice enclosure. Our study represents a preliminary step toward understanding how alpine stonefly cold tolerance varies at broad taxonomic and environmental scales (i.e., across species, populations, and habitats), setting the stage for future, more targeted studies of the group.

\section{METHODs}

Sampling and Environmental Data Collection

For SCP measurements, we collected lateinstar stonefly nymphs from 6 populations in the Rocky Mountains between 29 July and 6 August 2018 (Fig. 1, Table 1, Supplementary Material 3). To test whether high-elevation nemourids could survive being enclosed in ice, we collected additional late-instar L. tumana nymphs from Lunch Creek in Glacier National Park, Montana, on 17 August 2019. Nymphs were placed in 1-L Whirl-Pak ${ }^{\circledR}$ bags (Nasco) filled with streamwater and transported from the backcountry to the laboratory in ice-filled coolers. Transport duration depended on distance from a trailhead, ranging from a few hours (Lunch Creek) to more than $24 \mathrm{~h}$ (Mount Saint John). Populations were sampled from 2 Rocky Mountain subranges centered around Glacier and Grand Teton National Parks (Fig. 1). Due to the remote rugged terrain and high seasonal snowfall in the Rocky Mountains, we targeted our specimen collections to occur in late summer, soon after most streams in our study area became free of seasonal snow. We identified specimens based on morphology and collection localities following previous studies (e.g., Giersch et al. 2017). Unlike Lednia, multiple Zapada species can be present in the same stream; therefore, we cannot exclude the presence of more than one species in the Wind Cave population (Table 1).

We collected environmental data at each site to characterize the temperatures nymphs experience in the wild and to categorize sites by habitat type (e.g., glacier-fed, snowmelt-fed, or groundwater-fed stream, or high-elevation 
TABLE 1. Environmental variation and habitat types included in this study. $\mathrm{T}_{\text {MIN }}$ and $\mathrm{T}_{\mathrm{MEAN}}$ are the minimum and mean temperatures observed for each site, respectively. $\mathrm{C}=$ specific conductivity $\left(\mu \mathrm{S} \cdot \mathrm{cm}^{-1}\right)$; PI $=$ Pfankuch index, a measure of stream channel stability (higher values correspond to a less stable streambed); SCP = mean and standard deviation of the supercooling point. The focal 24-h period for temperature measurement was 31 July 2019 for all sites except Lunch Creek (31 July 2014) and Wind Cave (28 July 2019). All temperatures ( $\mathrm{T}_{\text {MIN }}, \mathrm{T}_{\mathrm{MEAN}}$, SCP) are in degrees Celsius. All sites are in Grand Teton National Park except Lunch Creek (Glacier National Park).

\begin{tabular}{lllcrlrl}
\hline Population & Taxon & Type & $\mathrm{T}_{\text {MIN }}$ & $\mathrm{T}_{\text {MEAN }}$ & \multicolumn{1}{c}{ C } & PI & SCP \\
\hline Lunch Creek & L. tumana & Snowmelt & 4.2 & 6.2 & 40.8 & 25 & $-5.9 \pm 2.0$ \\
Wind Cave & Zapada spp. & Icy seep & 2.6 & 2.8 & 101.1 & 18 & $-7.2 \pm 2.0$ \\
Mt. Saint John & L. tetonica & Icy seep & 2.4 & 3.0 & 25.0 & 34 & $-5.8 \pm 0.7$ \\
Cloudveil Dome & L. tetonica & Glacier-fed & 1.8 & 2.0 & 4.1 & 32 & $-7.0 \pm 0.9$ \\
Skillet Glacier & L. tetonica & Glacier-fed & 2.7 & 4.4 & 3.1 & 34 & $-5.2 \pm 1.1$ \\
Tetonica Pond & L. tetonica & Pond & 2.6 & 3.1 & 29.3 & n/a & $-7.5 \pm 1.3$ \\
\hline
\end{tabular}

aNamed by the authors. Does not reflect official conventions.

pond; see below). We recorded temperature hourly with HOBO loggers (Onset Computer Corporation) placed within about $5 \mathrm{~cm}$ of the main channel streambed. Lengths of logger deployments ranged from $<24 \mathrm{~h}$ (Mount Saint John, Tetonica Pond) to a full calendar year (Lunch Creek, Skillet Glacier, Wind Cave). Using these data, we constructed 24-h thermographs for each site on a representative day in late July. Our focal 24 -h period was 31 July 2019 for all sites except Lunch Creek (31 July 2014) and Wind Cave (28 July 2019). For the focal period, we measured the lowest $\left(\mathrm{T}_{\mathrm{MIN}}\right)$ and mean $\left(\mathrm{T}_{\text {MEAN }}\right)$ temperatures. We also measured specific conductivity $(\mathrm{C})$ with a YSI Professional ProPlus multiparameter probe (YSI Inc., Yellow Springs, OH), which was calibrated at the trailhead before each trip. Specific conductivity reflects ionic concentration in the water and is elevated in water that interacts with inorganic debris (e.g., streams fed by debriscovered rock glaciers). We assessed stream channel stability via a modified version of the Pfankuch Index (PI; Peckarsky et al. 2014). We estimated when sites became ice-free in 2018 using satellite imagery (Copernicus Sentinel 2).

We classified sites into one of 4 habitat types based on a combination of primary hydrological source, environmental variation, geomorphology, and field surveys. Habitat types included streams fed by a surface glacier (e.g., "glacier-fed"), streams fed by a perennial snowfield ("snowmelt-fed"), streams emanating from subterranean ice (e.g., rock glaciers, "icy seep"; Hotaling et al. 2019, Tronstad et al. 2020), and slow-flowing alpine ponds ("pond"). Alpine ponds were identified by their lowangle profile and the appearance of standing water. To discern among the 3 stream types, we relied on geographic data paired with the environmental signature of primary hydrological sources-glaciers, snowfields, or subterranean ice masses. Glacier-fed streams were identified by 4 criteria: named glaciers feeding them, low minimum temperatures $\left(\mathrm{T}_{\mathrm{MIN}}<3{ }^{\circ} \mathrm{C}\right)$, low $\mathrm{C}\left(<10 \mu \mathrm{S} \cdot \mathrm{cm}^{-1}\right)$, and high PI $(>25$, indicating more unstable stream channels). Streams were classified as snowmelt-fed by 4 criteria: a permanent snowfield visibly feeding them, higher minimum temperatures $\left(\mathrm{T}_{\mathrm{MIN}}>3{ }^{\circ} \mathrm{C}\right)$, moderate $\mathrm{C}\left(10-50 \mu \mathrm{S} \cdot \mathrm{cm}^{-1}\right)$, and a moderately stable stream channel $(\mathrm{PI}=18-25)$. We categorized streams as icy seeps by these 4 criteria: no named glaciers or significant perennial snowfields feeding them, consistently low temperatures (e.g., $\mathrm{T}_{\text {MEAN }} \leq 3{ }^{\circ} \mathrm{C}$ ), a classic "lobe" of a rock glacier visible (e.g., Mount Saint John), and moderate to high $\mathrm{C}$ for mountain streams $\left(>25 \mu \cdot \mathrm{cm}^{-1}\right)$.

\section{Measuring Supercooling Points}

In the laboratory, nymphs were held at $3{ }^{\circ} \mathrm{C}$ with no access to food for 12-72 h (Supplementary Material 3). For each SCP measurement, we blotted nymphs with Kimwipes (KimberlyClark, Irving, TX) and placed them in dry 1.5-mL microcentrifuge tubes. A 30-gauge Ttype thermocouple (2-mm soldered tip) was held in contact with each nymph's abdomen by a piece of cotton wedged into the tube. Thermocouples were attached to 4-channel loggers (UX-120, $\pm 0.6{ }^{\circ} \mathrm{C}$ accuracy; Onset Computer Corporation, Bourne, MA). Up to 12 microcentrifuge tubes were placed in an aluminum block in contact with a thermoelectric cooler, which was attached to a heat sink immersed in a glycol bath on the opposite face. We used a custom temperature controller to decrease the temperature at a rate of approximately $0.5-1{ }^{\circ} \mathrm{C}$ per minute. We estimated the 
SCP as the lowest recorded temperature before observing the transient increase in temperature as the body released latent heat and started to freeze. After SCPs were recorded for all nymphs in a given experimental group, we promptly removed them from the experimental bath. Nymphs were clearly dead upon removal from the microcentrifuge tubes after the SCP tests, with no movement for several minutes and no response to probing. Using a microscope and ocular scale, we subsequently measured body length to the nearest millimeter for all specimens.

\section{Testing Tolerance to Ice Enclosure}

We assessed whether late-instar L. tumana nymphs could survive being enclosed in ice, a potential environmental risk factor in highelevation streams and ponds. After collection, nymphs were maintained at $5{ }^{\circ} \mathrm{C}$ in the laboratory for $72 \mathrm{~h}$, with no access to food during that time. We then placed a single nymph in each well of an ice-cube tray with approximately $22 \mathrm{~mL}$ of streamwater. Nymphs were assigned to 1 of 3 treatments: $-0.5{ }^{\circ} \mathrm{C}$ (freezing, $n=8$ ), $0.1{ }^{\circ} \mathrm{C}$ (near freezing, $n=13$ ), or control $\left(5{ }^{\circ} \mathrm{C}, n=6\right)$. Thermocouples were inserted into the wells to monitor temperature. Once the streamwater reached the desired temperature, we began the treatment, which lasted for $3 \mathrm{~h}$. Following the experiment, we placed nymphs at $5{ }^{\circ} \mathrm{C}$ to recover for $7 \mathrm{~h}$. After the recovery period, we assessed survival by observation and gentle prodding.

\section{Statistical Analyses}

We performed all analyses in $\mathrm{R}$ ( $\mathrm{R}$ Core Team 2017). We first conducted an ANOVA to assess the effects of body length on SCP across all species. Next, to test whether there were differences in SCP across populations, we conducted an ANOVA using population as the predictor variable and SCP as the response variable. A Tukey HSD correction for multiple comparisons was used to compare the mean SCP for each pair of streams. We used the same approach (ANOVA with Tukey HSD correction) to estimate the effect of habitat type (glacier-fed, snowmelt-fed, icy seep, or pond) or species (L. tumana, L. tetonica, or Zapada spp.) on SCP. Finally, we tested for populationspecific variation in SCP for L. tetonica. We included body length as a covariate in all models to account for body size effects.

\section{Results}

\section{Environmental Variation and Habitat Types}

The sites sampled in this study represented 4 habitat types (Table 1). Tetonica Pond was the only site that lacked steep flowing water, and thus was the only "pond" we included. We also sampled 2 glacier-fed streams (Cloudveil Dome, Skillet Glacier outlet), 2 icy seeps (Wind Cave, Mount Saint John), and 1 snowmelt-fed stream (Lunch Creek). Over the focal 24-h period, minimum temperature was lowest at Cloudveil Dome $\left(\mathrm{T}_{\mathrm{MIN}}=1.8^{\circ} \mathrm{C}\right)$ and highest at Lunch Creek $\left(\mathrm{T}_{\mathrm{MIN}}=4.2{ }^{\circ} \mathrm{C}\right.$; Table 1$)$. Mean temperature followed the same pattern, with Cloudveil Dome being the coldest $\left(\mathrm{T}_{\text {MEAN }}\right.$ $=2.0{ }^{\circ} \mathrm{C}$ ) and Lunch Creek the warmest $\left(\mathrm{T}_{\text {MEAN }}=6.2^{\circ} \mathrm{C}\right.$; Table 1$)$. For all sites except Wind Cave, seasonal snow cover persisted well into July (Supplementary Material 3). For Lunch Creek, Wind Cave, and Skillet Glacier, full-year thermographs indicate that the main stream channel remains unfrozen year-round (Supplementary Material 2), but whether this lack of freezing extends to the streambed and margins is unknown.

\section{Supercooling Points}

Across all species, populations, and habitats, the mean SCP was $-6.5 \pm 1.7{ }^{\circ} \mathrm{C}$ (Table 1 ). Larger nymphs had higher SCPs than smaller nymphs $\left(F_{1,101}=7.14, P=0.009\right.$; Supplementary Material 4); we therefore included body length as a covariate in our statistical models. We found significant differences in SCPs among species $\left(F_{2,109}=3.25, P=0.043\right.$; Fig. $2 \mathrm{~A})$, populations $\left(F_{7,95}=4.528, P[\right.$ ANOVA $]<$ $0.001)$, and habitats $\left(F_{4,98}=4.556, P=0.002\right)$. Within a single species, L. tetonica, the SCP varied significantly among habitats $\left(F_{3,62}=\right.$ 10.4, $P<0.001$; Fig. 2B). Individuals from Tetonica Pond had the lowest mean SCP overall $\left(-7.5 \pm 1.3{ }^{\circ} \mathrm{C}\right.$, Table 1$)$ and those from glacier-fed streams had the highest (Table 1).

\section{Tolerance to Ice Enclosure}

No L. tumana nymphs $(n=0$ of 8$)$ in the freezing treatment $\left(-0.5{ }^{\circ} \mathrm{C}\right)$ survived being entirely enclosed in ice. In the near-freezing treatment $\left(0.1{ }^{\circ} \mathrm{C}\right)$, about $84 \%$ of nymphs $(n=$ 7 of 8) survived. A thin layer of ice formed on the surface of the well during the treatment, but the remainder of the streamwater beneath it, which contained each nymph, did not freeze. 


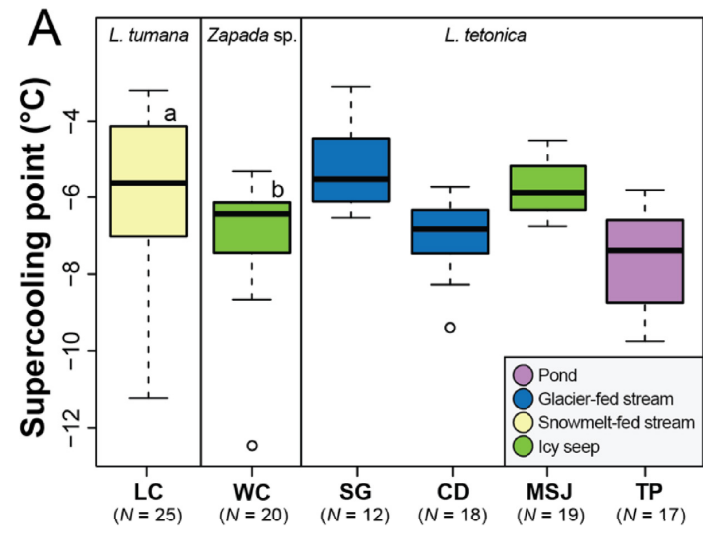

Population

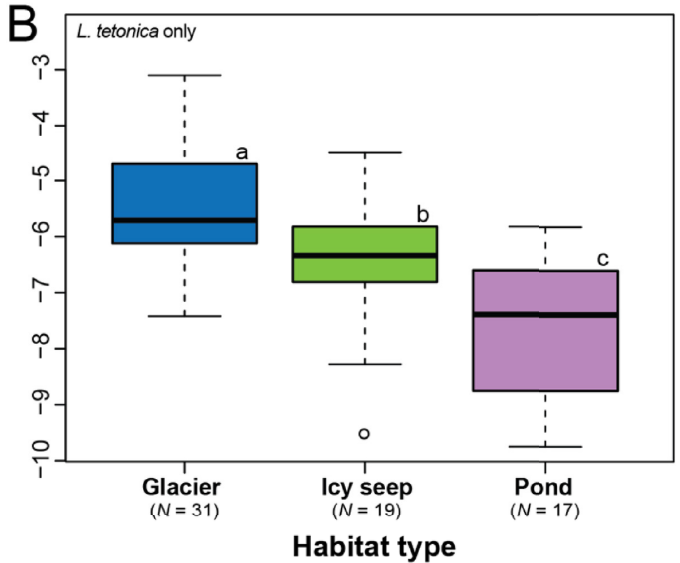

Fig. 2. Box-and-whisker plots of the supercooling point (SCP) of alpine stonefly nymphs in the Rocky Mountains, grouped by species and population $(A)$ and habitat type for Lednia tetonica only $(B)$. In each plot, groups of lowercase letters are significantly different at Tukey's HSD-corrected $P<0.05$ (see Supplementary Material 5 for detailed statistics). Dark lines represent median values in the data. Upper and lower bounds of the box are the upper and lower quartiles, respectively. Outliers are indicated by open circles. Population initialisms: $\mathrm{LC}=$ Lunch Creek, WC $=$ Wind Cave, $\mathrm{SG}=$ Skillet Glacier, $\mathrm{CD}=$ Cloudveil Dome, MSJ $=$ Mount Saint John, and TP $=$ Tetonica Pond .

All nymphs survived the $5{ }^{\circ} \mathrm{C}$ control treatment $(n=6$ of 6$)$.

\section{DISCUSSION}

Stoneflies are a major component of aquatic biodiversity in mountain ecosystems, yet little is known of their ability to cope with low temperatures, particularly as it relates to potential freezing stress. In this study, we measured supercooling points (SCPs) and tolerance to ice enclosure for high-elevation stonefly nymphs in the Rocky Mountains in order to link their physiological traits to the thermal regimes they experience. Our SCP estimates aligned with those described for other aquatic insects $\left(-3.3\right.$ to $-7.4{ }^{\circ} \mathrm{C}$; Moore and Lee 1991) and varied by species, population, and habitat. Because SCPs are typically higher for aquatic insects in summer versus in winter, the values observed in our study likely reflect maximum dry SCPs for our focal species (Moore and Lee 1991). Within L. tetonica, the alpine pond population exhibited lower SCPs than populations from icy seeps (and the lowest mean SCP of any population, $-7.5 \pm 1.3{ }^{\circ} \mathrm{C}$ ), which in turn had lower SCPs than populations from glacier-fed streams. Based on our results, we cannot disentangle the mechanism driving these patterns of cold tolerance (i.e., plasticity or local adaptation), but a correlation between thermal regime and SCP appears to exist.
Although hydrologically connected to steep, fast-flowing streams, the small size, shallowness, and extremely slow flow of Tetonica Pond likely elevates the winter freezing risk for resident taxa; alpine ponds in the Rocky Mountains often freeze solid in winter (Wissinger et al. 2016). Snow cover persisted on Tetonica Pond until mid-July in 2018 (Supplementary Material 3), suggesting it also may have been frozen late into the summer. An alternative explanation for the variation in SCPs we observed across habitats is the potential for differences in gut contents given the range of holding periods (12-72 h; Supplementary Material 3). Because gut contents can include efficient icenucleating agents (and raise SCPs; Danks 2008), we would expect higher SCPs for populations that were held for the shortest amount of time, if this was confounding our results. However, Tetonica Pond had one of the shortest holding periods (12 h) coupled with the lowest SCP (Table 1, Supplementary Material 3).

Because we tested SCPs in the absence of ice, it is likely that the inoculative freezing temperatures of our focal species are much higher than the values we report. For example, when $N$. arctica is in contact with ice, its SCP is $-1.5^{\circ} \mathrm{C}$, but in the absence of ice, $N$. arctica supercools to $-7.8{ }^{\circ} \mathrm{C}$ (Walters et al. 2009), a value that aligns with the range we observed $\left(-7.5\right.$ to $-5.2{ }^{\circ} \mathrm{C}$; Table 1$)$. Our ice enclosure experiment results also support the potential 
for higher inoculative freezing temperatures for L. tumana nymphs in contact with ice. Indeed, nymphs collected in late August did not survive being enclosed in ice, even at temperatures just below freezing $\left(-0.5^{\circ} \mathrm{C}\right)$. It is unclear, however, if the nymphs died due to inoculative freezing or due to something else (e.g., internal mechanical damage or hypoxia). Nevertheless, a similar result was found for $N$. arctica. In mid-August, $<20 \%$ of $N$. arctica nymphs survived a 2 -h exposure to $-1.5{ }^{\circ} \mathrm{C}$. Yet by late September, when stream temperatures are colder and closer to $0{ }^{\circ} \mathrm{C}$, more than $80 \%$ survived a 7 - $\mathrm{d}$ exposure to $-6.2{ }^{\circ} \mathrm{C}$, suggesting that this species exhibits plasticity in cold tolerance (Walters et al. 2009). Although testing for seasonal plasticity in freeze tolerance was beyond the scope of our study, when typical summer conditions prevail (e.g., $\mathrm{T}_{\mathrm{MEAN}}$ $\left.>5{ }^{\circ} \mathrm{C}\right)$, L. tumana nymphs from Lunch Creek are intolerant of even mild subzero temperatures. But unlike the Chandalar River in Alaska, where $N$. arctica resides and temperatures reach $-10{ }^{\circ} \mathrm{C}$ at the sediment-water interface in winter, streams in the high Rocky Mountains appear to rarely, if ever, fall below $0{ }^{\circ} \mathrm{C}$. Indeed, for the streams in this study for which we have full-year thermographs (Supplementary Material 2), only Lunch Creek approached $0{ }^{\circ} \mathrm{C}$ at any point during the year. This thermal buffering likely reflects high levels of insulating snow in the region. However, our reported temperatures reflect the thermal conditions of the main stream channel. At stream margins, where flows are slower and less water is available for thermal buffering, temperatures may be quite different.

In this study, we showed that SCPs vary among species, populations, and habitat types for stonefly nymphs inhabiting Rocky Mountain headwaters. The population most likely to experience winter freezing stress also exhibited the lowest SCP, suggesting a potential ecological role for SCP in freeze avoidance among alpine stoneflies. Our results, of course, apply only to nymphs, one of the 3 life stages of stoneflies: eggs, nymphs (i.e., larvae), and adults. We focused on nymphs because this stage is the key period when most growth occurs. Highelevation nemourid stoneflies appear to spend at least one winter as larvae (Supplementary Material 1), and statistical models indicate that a species' vulnerability to climate change can be greatly underestimated when the larval period is overlooked (Levy et al. 2015). With evidence across stonefly species that cryoprotective dehydration greatly lowers the freezing point of eggs (Gehrken and Sømme 1987), that nymphs have the ability to survive ice enclosure (Walters et al. 2009), and that adults emerge in winter (e.g., Bouchard et al. 2009), it is clear that stoneflies can survive freezing conditions across all life stages. However, the degree to which freeze tolerance is common or rare, and the degree to which cold tolerance varies across life stages within species are key questions for future study.

As climate change proceeds, glaciers and perennial snowfields are receding, reducing mountain streamflow (Hotaling et al. 2017) and habitat for high-elevation aquatic invertebrates (Domisch et al. 2011, Muhlfeld et al. 2020). Loss of meltwater, higher ambient temperatures, and rapid contemporary stream warming (e.g., Niedrist and Füreder 2020) are raising the risks to headwater biodiversity, including risks to many stoneflies that are considered cold-water stenotherms (Tierno de Figueroa et al. 2010, Domisch et al. 2011, but see Hotaling et al. 2020). Reduced streamflow will lower the thermal buffering capacity of streamwater (Shah et al. 2020) and, despite warmer winter temperatures, it will also increase the potential for freezing stress (Williams et al. 2015). This effect will likely be compounded by decreasing levels of insulating snowpack as more winter precipitation falls as rain instead of snow (e.g., Huntington et al. 2004). Specifically, if snowpack accumulates later or melts off earlier, freezing risk in transitional periods between seasons (e.g., November and June in the Northern Hemisphere) may increase. Thus, a greater risk of freezing may represent an overlooked climate change threat to alpine aquatic biodiversity. Although only 2 stoneflies are known to actively mitigate freezing stress during nonadult stages (Gehrken 1989, Walters et al. 2009), it is unclear whether this mitigation reflects general stonefly biology or a lack of investigation.

\section{Supplementary Material}

Five online-only supplementary files accompany this article (https://scholarsarchive.byu .edu/wnan/vol81/iss1/5).

Supplementary Material 1. Two size classes of Lednia tumana present in a quantitative September 
sample of the macroinvertebrate community from Lunch Creek, Montana, USA.

Supplementary Material 2. Daily mean temperatures for the 3 streams included in this study with a complete year of temperature data. Wind Cave and Skillet Glacier data are from 2016 to 2017. Lunch Creek was measured in 2013-2014.

Supplementary Material 3. Additional details about the populations used in this study (e.g., latitude and longitude) as well as experimental conditions (e.g., holding period, sample size).

Supplementary Material 4. Stonefly nymph length versus supercooling point (SCP) and boxplots of body length by species.

Supplementary Material 5. Tukey-adjusted differences in supercooling point (SCP) for pairs of populations.

\section{ACKNOWLEDGMENTS}

We acknowledge long-term funding from the University of Wyoming-National Park Service Research Station (http://uwnps.org). SH and JLK were supported by NSF awards OPP-1906015 and IOS-1557795. AAS was supported by an NSF Postdoctoral Research Fellowship in Biology (DBI-1807694). MED was supported by NSF awards DEB-1457659, OIA-1826834, and EF-1921562. HAW was supported by a grant from the Montana Water Center. We thank Taylor Price and Lydia Zeglin for field support. Jordan Boersma, Georg Niedrist, and Brent Sinclair provided valuable comments on the manuscript.

\section{Literature Cited}

Bouchard, R.W. Jr., B.E. Schuetz, L.C. Ferrington Jr., AND S.A. KELLS. 2009. Cold hardiness in the adults of two winter stonefly species: Allocapnia granulata (Claassen, 1924) and A. pygmaea (Burmeister, 1839) (Plecoptera: Capniidae). Aquatic Insects 31: $145-155$.

Brighenti, S., S. Hotaling, D.S. Finn, A.G. Fountain, M. Hayashi, D. Herbst, J.E. Saros, L.T. Tronstad, AND C.I. MiLLAR. 2021. Rock glaciers and related cold rocky landforms: overlooked climate refugia for mountain biodiversity. Global Change Biology 27: 1504-1517.

Brittain, J.E., AND B. Nagell. 1981. Overwintering at low oxygen concentrations in the mayfly Leptophlebia vespertina. Oikos 36:45-50.

Conradi-Larsen, E., and L. Sømme. 1973. Anaerobiosis in the overwintering beetle Pelophila borealis. Nature 245:388-390.

DanKs, H. 1971. Overwintering of some north temperate and Arctic Chironomidae: II. Chironomid biology. Canadian Entomologist 103:1875-1910.

DANKs, H.V. 2008. Aquatic insect adaptations to winter cold and ice. Pages 1-19 in J. Lancaster and R.A.
Briers, editors, Aquatic insects: challenges to populations. Institute of Evolutionary Biology, University of Edinburgh, Ashworth Labs, West Mains Road, Edinburgh EH9 3JT, UK.

DeWalt, R.E., B.C. Kondratieff, and J.B. Sandberg. 2015. Order Plecoptera. Pages 933-949 in J.H. Thorp and D.C. Rogers, editors, Thorp and Covich's Freshwater Invertebrates. 4th edition. Volume 1, Ecology and General Biology. Academic Press.

Domisch, S., S.C. JäHnIG, AND P. HaASE. 2011. Climatechange winners and losers: stream macroinvertebrates of a submontane region in Central Europe. Freshwater Biology 56:2009-2020.

Duman, J.G. 2015. Animal ice-bind (antifreeze proteins) and glycolipids: an overview with emphasis on physiological function. Journal of Experimental Biology 218: $1846-1855$.

FrISBIE, M.P., AND R.E. LEE JR. 1997. Inoculative freezing and the problem of winter survival for freshwater macroinvertebrates. Journal of the North American Benthological Society 16:635-650.

Gehrken, U. 1989. Diapause termination in eggs of the stonefly Arcynopteryx compacta (McLachland) in relation to dehydration and cold hardiness. Journal of Insect Physiology 35:377-385.

GehrKen, U., AND L. Sømme. 1987. Increased cold hardiness in eggs of Arcynopteryx compacta (Plecoptera) by dehydration. Journal of Insect Physiology 33: 987-991.

Giersch, J.J., S. Hotaling, R.P. Kovach, L.A. Jones, and C.C. MuhlfELD. 2017. Climate-induced glacier and snow loss imperils alpine stream insects. Global Change Biology 23:2577-2589.

Hotaling, S., D.S. Finn, J.J. Giersch, D.W. Weisrock, AND D. JACOBSEn. 2017. Climate change and alpine stream biology: progress, challenges, and opportunities for the future. Biological Reviews 92:2024-2045.

Hotaling, S., M.E. Foley, L.H. Zeglin, D.S. Finn, L.M. Tronstad, J.J. Giersch, C.C. Muhlfeld, and D.W. WEISROCK. 2019. Microbial assemblages reflect environmental heterogeneity in alpine streams. Global Change Biology 25:2576-2590.

Hotaling, S., A.A. Shah, K.L. McGowan, L.M. Tronstad, J.J. Giersch, D.S. Finn, H.A. Woods, M.E. Dillon, AND J.L. KELley. 2020. Mountain stoneflies may tolerate warming streams: evidence from organismal physiology and gene expression. Global Change Biology 26:5524-5538.

Huntington, T.G., G.A. Hodgkins, B.D. Keim, and R.W. DudLEY. 2004. Changes in the proportion of precipitation occurring as snow in New England (19492000). Journal of Climate 17:2626-2636.

Huss, M., AND R. Hock. 2018. Global-scale hydrological response to future glacier mass loss. Nature Climate Change 8:135-140.

LENCIONI, V. 2004. Survival strategies of freshwater insects in cold environments. Journal of Limnology 63:45-55.

Levy, O., L.B. Buckley, T.H. KeitT, C.D. Smith, K.O. Boateng, D.S. Kumar, and M.J. Angilletta Jr. 2015. Resolving the life cycle alters expected impacts of climate change. Proceedings of the Royal Society B: Biological Sciences 282:20150837. 9 pp.

Moore, M.V., AND R.E. LeE JR. 1991. Surviving the big chill: overwintering strategies of aquatic and terrestrial insects. American Entomologist 37:111-118.

Muhlfeld, C.C., T.J. Cline, J.J. Giersch, E. Peitzsch, C. Florentine, D. Jacobsen, and S. Hotaling. 2020. 
Specialized meltwater biodiversity persists despite widespread deglaciation. Proceedings of the National Academy of Sciences 117:12208-12214.

Niedrist, G.H., AND L. FÜreder. 2020. Real-time warming of Alpine streams: (re)defining invertebrates' temperature preferences. River Research and Applications. https://doi.org/10.1002/rra.3638

Peckarsky, B.L., A.R. McIntosh, S.C. Horn, K. McHugh, D.J. Booker, A.C. Wilcox, W. Brown, And M. Alvarez. 2014. Characterizing disturbance regimes of mountain streams. Freshwater Science 33:716-730.

R CoRe Team. 2017. R: a language and environment for statistical computing. R Foundation for Statistical Computing, Vienna, Austria. https://www.R-project.org

Ricker, W.E. 1952. Systematic studies in Plecoptera. Indiana University Publications, Science Series 18.

Shah, A.A., M.E. Dillon, S. Hotaling, and H.A. Woods. 2020. High elevation insect communities face shifting ecological and evolutionary landscapes. Current Opinion in Insect Science 41:1-6.

Shah, A.A., B.A. Gill, A.C. Encalada, A.S. Flecker, W.C. Funk, J.M. Guayasamin, B.C. KondratiefF, N.L. Poff, S.A. Thomas, and K.R. Zamudio. 2017. Climate variability predicts thermal limits of aquatic insects across elevation and latitude. Functional Ecology 31:2118-2127.

Sinclair, B.J., L.E. Coello Alvarado, and L.V. FerguSON. 2015. An invitation to measure insect cold tolerance: methods, approaches, and workflow. Journal of Thermal Biology 53:180-197.

Tierno de Figueroa, J.M.T., M.J. López-Rodríguez, A. Lorenz, W. Graf, A. SChMidt-KLOIBER, AND D. Hering. 2010. Vulnerable taxa of European Plecoptera (Insecta) in the context of climate change. Biodiversity and Conservation 19:1269-1277.
Toxopeus, J., AND B.J. Sinclair. 2018. Mechanisms underlying insect freeze tolerance. Biological Reviews 93: 1891-1914.

Tronstad, L.M., S. Hotaling, J.J. Giersch, O.J. Wilmot, AND D.S. FInN. 2020. Headwaters fed by subterranean ice: potential climate refugia for mountain communities? Western North American Naturalist 80: 395-407.

Walters, K.R., A.S. Serianni, Y. Voituron, T. Sformo, B.M. Barnes, and J.G. Duman. 2011. A thermal hysteresis-producing xylomannan glycolipid antifreeze associated with cold tolerance is found in diverse taxa. Journal of Comparative Physiology B 181: 631-640.

Walters, K.R., T. SFormo, B.M. Barnes, and J.G. Duman. 2009. Freeze tolerance in an Arctic Alaska stonefly. Journal of Experimental Biology 212:305-312.

Williams, C.M., H.A. Henry, and B.J. Sinclair. 2015. Cold truths: how winter drives responses of terrestrial organisms to climate change. Biological Reviews 90: 214-235.

Wissinger, S.A., B. Oertui, And V. Rosset. 2016. Invertebrate communities of alpine ponds. Pages 55-103 in D. Baxter and D. Boix, editors, Invertebrates in freshwater wetlands. Springer, Cham.

Zachariassen, K.E. 1985. Physiology of cold tolerance in insects. Physiological Reviews 65:799-832.

Received 13 November 2019 Revised 16 June 2020 Accepted 23 July 2020 Published online 28 April 2021 